\title{
Preliminary data on the feeding habits of the freshwater stingrays Potamotrygon falkneri and Potamotrygon motoro (Potamotrygonidae) from the Upper Paraná River basin, Brazil
}

\author{
Thiago Buosi Silva ${ }^{1}$ \& Virgínia Sanches Uieda ${ }^{1,2}$ \\ Biota Neotropica v7 (n1) - http://www.biotaneotropica.org.br/v7n1/pt/abstract?article +bn02007012007 \\ Data Received 21/04/06 \\ Revised 12/09/06 \\ Accepted 24/01/07 \\ ${ }^{1}$ Departamento de Zoologia, Instituto de Biociências, CP 510, Universidade Estadual Paulista - UNESP, \\ CEP 18618-000 Botucatu, São Paulo,_Brazil, e-mail: thiago_buosi@yahoo.com.br \\ ${ }^{2}$ Corresponding author: Virgínia Sanches Uieda, e-mail: vsuieda@ibb.unesp.br
}

\begin{abstract}
Silva, T.B. \& Uieda, V.S. Preliminary data on the feeding habits of the freshwater stingrays Potamotrygon falkneri and Potamotrygon motoro (Potamotrygonidae) from the Upper Paraná River basin, Brazil. Biota Neotrop. Jan/Apr 2007 vol. 7, no. 1 http://www.biotaneotropica.org.br/v7n1/pt/abstract?article+bn02007012007 ISSN 1676-0603.

Stingrays of the Potamotrygonidae family are a singular group of Neotropical ichthyofauna. Although ancient reports exist about the group, there are still many questions that need to be clarified, such as the biology of the species that occur in the Paraná-Paraguay River system. In the present work, the diet of Potamotrygon falkneri and Potamotrygon motoro, captured in the Upper Paraná River, downstream from the Engenheiro Souza Dias Hydroelectric Power Station (UHE Jupiá), was analyzed. Both species showed a diversified diet, consisting of 14 food items, including Mollusca, Crustacea, Insecta and fish, with the predominance in diversity and abundance of aquatic insects. Only one individual of each species ingested fish. Potamotrygon motoro consumed mainly Ephemeroptera, while P. falkneri consumed mainly Mollusca, Hemiptera and Trichoptera. The data apparently indicate a more specialized diet for P. motoro, consuming more Ephemeroptera (Baetidae), and a more generalized diet for $P$. falkneri. The analysis of individuals captured in three microhabitats that differ in function of the substrate type and presence of marginal vegetation, suggests differences in the food items consumed.
\end{abstract}

Keywords: diet, rays, resource partitioning, microhabitat.

\section{Resumo}

Silva, T.B. \& Uieda, V.S. Dados preliminares sobre o hábito alimentar das raias de água doce Potamotrygon falkneri e Potamotrygon motoro (Potamotrygonidae), na Bacia do Alto Rio Paraná, Brasil. Biota Neotrop. Jan/Apr 2007 vol. 7, no. 1 http://www.biotaneotropica.org.br/v7n1/pt/abstract?article+bn02007012007 ISSN 1676-0603.

As raias da família Potamotrygonidae representam um grupo singular da ictiofauna Neotropical. Apesar de serem antigos os relatos sobre o grupo, ainda são muitas as questões que permanecem sem resposta, sobretudo no que diz respeito à biologia das espécies que ocorrem na Bacia do Paraná-Paraguai. No presente trabalho foi analisada a dieta de Potamotrygon falkneri e Potamotrygon motoro, capturadas no Alto Rio Paraná, a jusante da Usina Hidrelétrica Engenheiro Souza Dias (UHE Jupiá). As duas espécies de raias apresentaram dieta diversificada, ingerindo 14 itens, entre moluscos, crustáceos, insetos e peixes, porém com predominância de insetos aquáticos em diversidade e abundância. Somente um indivíduo de cada espécie ingeriu peixe. Potamotrygon motoro consumiu principalmente Ephemeroptera, enquanto P. falkneri, principalmente Mollusca, Hemiptera e Trichoptera. Os dados aparentemente indicam uma dieta mais especializada de $P$. motoro, com maior consumo de Ephemeroptera (Baetidae), e uma dieta mais generalizada de P. falkneri. A análise dos indivíduos capturados em três microhábitats, que diferem quanto ao tipo de substrato e presença de vegetação marginal, sugere diferenças nos tipos de alimentos consumidos.

Palavras-chave: dieta, raias, partilha de recursos, micro-hábitat. 


\section{Introduction}

Stingrays of the family Potamotrygonidae are important components of the Neotropical ichthyofauna, being the only group of elasmobranchs completely restricted to fluvial systems of South America (Thorson et al. 1978, Compagno \& Cook 1995, Lasso et al. 1996). Three genera are recognized within the family: Paratrygon Duméril, 1865, Plesiotrygon Rosa, Castello \& Thorson, 1987, and Potamotrygon Garman, 1877 (Carvalho et al. 2003). In some places they are captured as ornamental fishes and eventually used as food resource by fishermen communities (Charvet-Almeida et al. 2002). Few studies dealing with the biology of stingrays are restricted to species from the Amazon River basin (Araújo 1998, Charvet-Almeida 2001). In the Paraná-Paraguay River system, existent data are restricted to studies carried on during the decades of 1960 and 1970 in the region of Santa Fé, Argentina (Castex 1963a,b, Achenbach \& Achenbach 1976). Recently, some reports focused on the stingray invasion in the Upper Paraná River and their capacity to inflict injuries to humans (Haddad Jr. et al. 2004).

Potamotrygon motoro (Figure 1a) is the species with the highest occurrence and abundance in the Paraná River (Achenbach \& Achenbach 1976). It is distinguished from P. falkneri, also of common occurrence, by the presence of orange to yellow dorsal ocelli with a diameter larger than the eyes and rounded by a black ring (Britski et al. 1999). In contrast, on the dorsal surface of P. falkneri (Figure 1b)

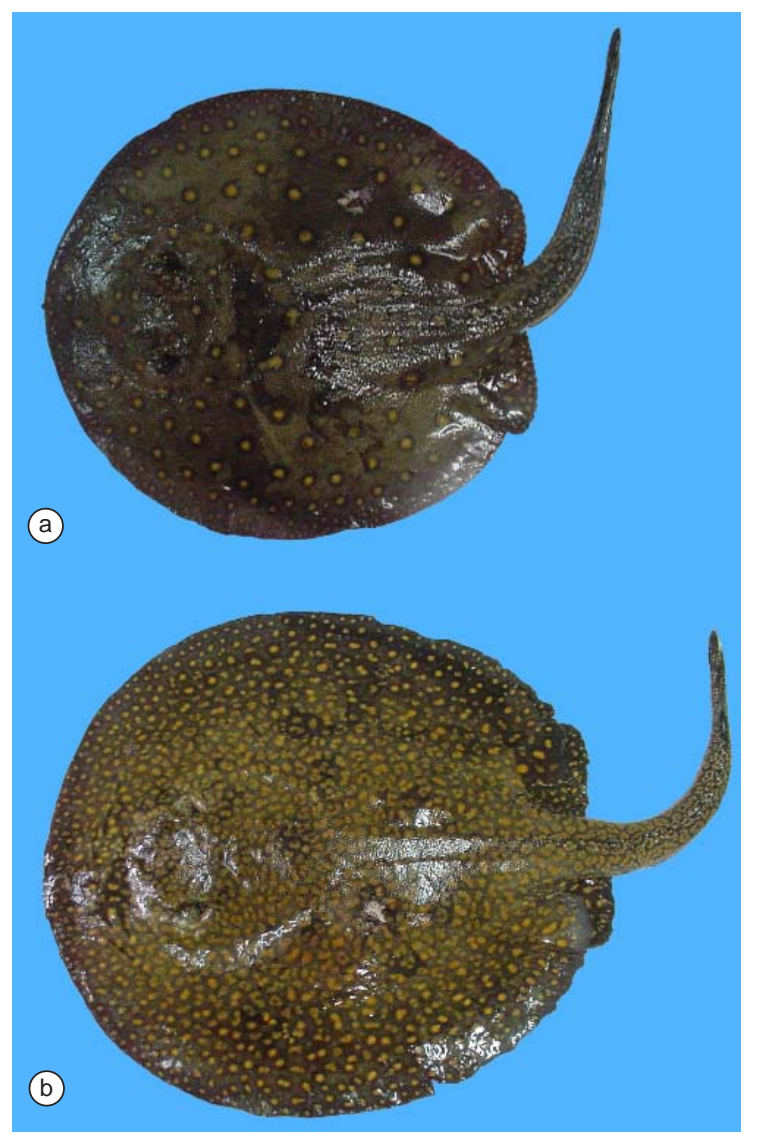

Figure 1. Potamotrygon motoro female with $265 \mathrm{~mm}$ of disk length a) and Potamotrygon falkneri female with $445 \mathrm{~mm}$ of disk length b) sampled in Paraná River close to UHE-Jupiá (Photos: Domingos Garrone Neto).

Figura 1. Fêmea de Potamotrygon motoro com $265 \mathrm{~mm}$ de largura de disco a) e fêmea de Potamotrygon falkneri com $445 \mathrm{~mm}$ de largura de disco b), amostradas no Rio Paraná, próximo a UHE-Jupiá (Fotos: Domingos Garrone Neto). irregular yellow spots commonly larger than eye diameter are present. Although the differentiation of those species may seem to be easy according to the description above, preliminary taxonomic studies have showed a strong polychromatic variation between individuals of different size and from different habitats, making the identification based only on morphological characteristics considerably difficult (D. Garrone Neto, unpublished data).

Considering the scarcity of studies on the biology and ecology of the great majority of stingray species that occur in the Paraná-Paraguay River system research on this subject is extremely important. The present study intends to contribute with data about the feeding habits of stingrays belonging to the Paraná River. Data on feeding habits are important for ecologists and, nowadays, for administrators of fishing resources, allowing a better comprehension of the function of the ecosystem and, thus, their proper management (Zavala-Camim 1996). The Paraná-Paraguay River system has been intensely modified, including alterations in the original fauna composition. Therefore, information on invading species such as the rays becomes important for the administration of this ecosystem and future conservation projects.

\section{Material and Methods}

The work was carried out in the Upper Paraná River, in the region of the Engenheiro Souza Dias Hydroelectric Power Station - UHE Jupiá reservoir $\left(20^{\circ} 47^{\prime} \mathrm{S}\right.$ and $\left.51^{\circ} 38^{\prime} \mathrm{W}\right)$. The UHE Jupiá is situated between Castilho (São Paulo State) and Três Lagoas (Mato Grosso do Sul State), in the Midwestern region of Brazil. Dam is 5,495 m long and the flooded area of the reservoir lake amounts to $330 \mathrm{~km}^{2}$. It was concluded in 1974 allowing navigation in the Paraná River (data supplied by Companhia Energética de São Paulo - CESP).

Specimens of Potamotrygon motoro and P. falkneri were sampled on April and May 2004, during daylight hours, with underwater fishing equipment (pneumatic harpoon, used by local fishermen). The samples were taken from three microhabitats downstream from the reservoir (Figure 2). The three sampled microhabitats differed in function of the substrate type and presence of marginal vegetation. All this downstream area has suffered a strong anthropic interference during the dam construction and the riparian vegetation is currently undergoing a recovery phase.

The first microhabitat (Figure 2a), located in the right margin and 50 to $800 \mathrm{~m}$ downstream from the dam, has rocky banks and substrate, a fast current and depths between 0.5 and $3 \mathrm{~m}$. The second microhabitat (Figure 2b), located in the left margin and 700 to $1,100 \mathrm{~m}$ downstream from the dam, presents submerged herbaceous vegetation, a muddy substrate and depths of 1.5 to $2.5 \mathrm{~m}$. The third microhabitat (Figure 2c), also in the left margin and continuous with the second microhabitat, presents riparian vegetation with trees up to $30 \mathrm{~m}$ high, sandy beaches, a rocky substrate in the riverbed and depths between 1.0 and $2.5 \mathrm{~m}$.

Collected specimens were identified using a key made by Rosa (1985), and afterwards they were weighed and measured (disk length and total length). The digestive tract was removed and fixed in $10 \%$ formalin. The diet was determined through the analysis of the stomach content under stereomicroscopy, and ingested food items were identified using specific keys for freshwater invertebrates (Pennak 1978, Ringuelet 1976) and aquatic insects (Lopretto \& Tell 1995, Merritt \& Cummins 1996). Frequency of occurrence, volume, and numerical frequency were the methods used. The frequency of occurrence (Hyslop 1980) indicates the presence or absence of each food item in the diet, being calculated as the number of fishes where the item occurred in relation to the total of occurrence of every item (relative frequency). The volume was determined in two ways: biovolume 

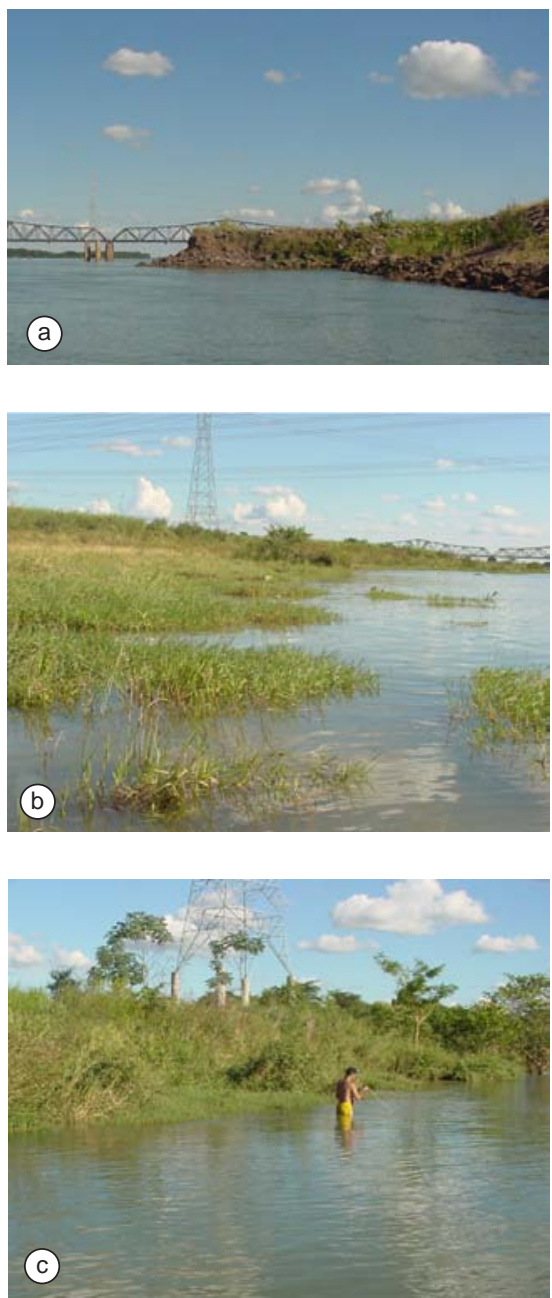

Figure 2. General view of the sampled microhabitats: rocky right margin a), muddy left margin b), and rocky left margin c) with detail of a fisherman harpooning a ray (Photos: Domingos Garrone Neto).

Figura 2. Vista geral dos microhabitats amostrados: margem direita rochosa a), margem esquerda lodosa b), e margem esquerda rochosa c) com detalhe de um pescador arpoando uma raia (Fotos: Domingos Garrone Neto)

and relative volume. The biovolume corresponds to the area occupied by each food item in relation to the totality of ingested items, determined by the analysis of the stomach content on a milimetric plate (adapted from Esteves \& Galetti Jr. 1995). The relative volume was determined through the displacement of a water column, using a graduated test tube. For the item "fishes", only the relative volume was calculated. The numerical frequency (Hyslop 1980) corresponds to the percentage calculated as the number of individuals for each ingested item in relation to the total number of individuals of all items. This value was associated to the frequency of occurrence and volume for the calculation of the Relative Index of Importance (Pinkas et al. 1971), in which the predominant food in the diet was defined, as follows: $\mathbf{R I I}=(\mathrm{NF}+\mathrm{V}) \times \mathbf{F O}$; $\mathbf{R I I}=$ relative index of importance; $\mathrm{NF}=$ numerical frequency; $\mathrm{V}=$ biovolume or relative volume; FO $=$ frequency of occurrence. To allow the diet comparison among species, calculated values of RII were transformed into relative values (\%). Items with values of RII higher than $20 \%$ were considered as the predominant food in the species diet.

\section{Results and Discussion}

The commercial rays capture is usually done with a line with multiple hooks (a long line called "espinhel") or with a harpoon in the area of study. The latter method, used in the present work, gives a better result in terms of captured individuals by capture effort and allows the sampling of specific microhabitats. The commercial capture of stingray is only done by accident (the rays are caught in the long line when trying to eat the bait intended for other fish species) and the harpoon capture is only done when specifically asked for, since no commerce of rays for human consumption exists in the general studied area (M. J. Vilela, pers. comm.). Currently only some of the professional fishermen eat ray meat, since it does not present any commercial importance. Although it occurred more frequently in the past, even today the rays captured by professional and amateur fishermen in the general area of study usually have their stings removed, after which they are reintroduced in the river (D. Garrone Neto, pers. comm.). A total of 25 stingrays were captured, being 15 P. motoro and 10 P. falkneri. Potamotrygon motoro specimens presented a total length between 257 and $457 \mathrm{~mm}$, disk length between 168 and $265 \mathrm{~mm}$, and weight between 380 and $980 \mathrm{~g}$. Potamotrygon falkneri specimens presented 531 to $835 \mathrm{~mm}$ of total length, 254 to $445 \mathrm{~mm}$ of disk length, and a weight of 940 to $6550 \mathrm{~g}$. Although the sampled specimens of $P$. motoro were smaller than the other species, Thorson et al. (1983) reported that this species reaches a maximum length of $600 \mathrm{~mm}$ and $8.5 \mathrm{~kg}$ of weight. Although the literature about $P$. falkneri is scarce, a maximum length of $892 \mathrm{~mm}$ was cited for this species (Britski et al. 1999).

The two species showed a diversified diet, a common characteristic of fluvial fish (Weatherley 1963, Lowe-McConnell 1999), ingesting 14 different food items, including Mollusca, Crustacea, aquatic Insecta and fishes (Table 1), with predominance of aquatic insects both in diversity and abundance. Despite presenting high diversity, Mollusca and Crustacea were consumed in low percentages. Only one individual of each species ingested fish. The two species differed in relation to the predominant type of aquatic insect ingested: P. motoro fed mainly on Ephemeroptera (Baetidae) and Diptera (Chironomidae), whereas P. falkneri fed mainly on Trichoptera (Odontoceridae) and Hemiptera (Naucoridae) (Table 1).

According to Achenbach \& Achenbach (1976), the feeding habits of Potamotrygonidae rays change during ontogenetic development, with young rays feeding on small mollusks, crustaceans, and insect larvae, while adults feed on fishes and crabs. The ingestion of fishes of the family Loricariidae was also reported by this author. For P. motoro, it seems that the majority of captured individuals were juveniles, with the sampled individuals having $1 / 3$ and $1 / 8$ of the size and weight, respectively, of the largest individuals reported in the literature (data from Thorson et al. 1983). In addition, according to Achenbach \& Achenbach (1976), reproductively mature individuals of $P$. motoro present disk sizes between 300 and $350 \mathrm{~mm}$, larger than the disk sizes presented by the individuals collected in this study. In this way, the insectivorous diet of $P$. motoro may represent an ontogenetic diet variation. In the case of $P$. falkneri, the absence of reported data concerning the length of adults leaves this possibility open.

The relative index of importance (RII) reinforced the feeding differences between the two ray species. Potamotrygon motoro ingested mainly Ephemeroptera (Table 2) and P. falkneri, with a more diversified diet, ingested a high percentage of Mollusca, Hemiptera and Trichoptera (Table 3). Despite these differences, P. motoro and P. falkneri showed some similarities with data from other stingray species. Potamotrygon orbigny from the Venezuelan llanos also showed preference for aquatic insects, mainly Diptera (Chironomidae) and Ephemeroptera (Lasso et al. 1996). In contrast, a carnivorous 
Table 1. Frequency of occurrence (FO\%) and numerical frequency (NF\%) of the food items consumed by Potamotrygon motoro and P. falkneri.

Tabela 1. Freqüência de ocorrência (FO\%) e freqüência numérica (NF\%) dos itens alimentares consumidos por Potamotrygon motoro e P. falkneri.

\begin{tabular}{|c|c|c|c|c|}
\hline \multirow[t]{2}{*}{ Consumed food } & \multicolumn{2}{|c|}{ P. motoro } & \multicolumn{2}{|c|}{ P. falkneri } \\
\hline & FO & NF & FO & NF \\
\hline 1. Bivalvia (fragments) & - & - & 4.0 & 2.0 \\
\hline 2. Gastropoda (Ampullariidae) & 2.4 & 0.3 & 8.0 & 5.9 \\
\hline 3. Gastropoda (Hydrobiidae) & 2.4 & 0.3 & 4.0 & 2.0 \\
\hline 4. Gastropoda (fragments) & - & - & 4.0 & 2.0 \\
\hline 5. Crustacea (Palaemonidae) & 2.4 & 0.3 & - & - \\
\hline 6. Crustacea (fragments) & - & - & 4.0 & 2.0 \\
\hline 7. Coleoptera (Elmidae) & 2.4 & 0.3 & - & - \\
\hline 8. Diptera (Chironomidae) & 22.0 & 10.3 & 4.0 & 11.8 \\
\hline 9. Ephemeroptera (Baetidae) & 29.3 & 76.8 & 12.0 & 15.7 \\
\hline 10. Hemiptera (Naucoridae) & 2.4 & 0.3 & 12.0 & 25.5 \\
\hline 11. Lepidoptera (Pyralidae) & 2.4 & 0.1 & - & - \\
\hline 12. Odonata (Cordullidae) & 2.4 & 0.3 & - & - \\
\hline 13. Odonata (Gomphidae) & 7.3 & 1.3 & 8.0 & 3.9 \\
\hline 14. Odonata (Libellulidae) & - & - & 4.0 & 5.9 \\
\hline 15. Trichoptera (Hydropsychidae) & 7.3 & 3.2 & 4.0 & 2.0 \\
\hline 16. Trichoptera (Leptoceridae) & 7.3 & 1.6 & 8.0 & 3.9 \\
\hline 17. Trichoptera (Odontoceridae) & 7.3 & 3.9 & 20.0 & 13.7 \\
\hline 18. Fish (Loricariidae) & - & - & 4.0 & 3.9 \\
\hline 19. Fish (fragments) & 2.4 & 0.3 & - & - \\
\hline Number of analyzed individuals & \multicolumn{2}{|c|}{15} & \multicolumn{2}{|c|}{10} \\
\hline Number of empty stomachs & \multicolumn{2}{|c|}{0} & \multicolumn{2}{|c|}{2} \\
\hline
\end{tabular}

Table 2. Food items consumed by Potamotrygon motoro and their frequency of occurrence (FO\%), numerical frequency (NF\%), biovolume (B\%), and relative volume (RV\%). The Relative Index of Importance (RII) was calculated using the biovolume and the relative volume values. The numbers in bold represent the predominant items in the diet $(>20 \%)$.

Tabela 2. Itens alimentares consumidos por Potamotrygon motoro e sua freqüência de ocorrência (FO\%), freqüência numérica (NF\%), biovolume (B\%) e volume relativo (RV\%). O Índice de Importância Relativa (RII) foi calculado usando os valores do biovolume e do volume relativo. Os números em negrito representam os itens predominantes na dieta $(>20 \%)$.

\begin{tabular}{|c|c|c|c|c|c|c|c|c|}
\hline \multirow[t]{2}{*}{ Consumed food } & \multirow[t]{2}{*}{ FO } & \multirow[t]{2}{*}{$\mathbf{N F}$} & \multirow[t]{2}{*}{ B } & \multirow[t]{2}{*}{$\mathbf{R V}$} & \multicolumn{2}{|c|}{ RII (biovolume) } & \multicolumn{2}{|c|}{ RII (relative volume) } \\
\hline & & & & & RII & RII \% & RII & RII \% \\
\hline Mollusca & 2.7 & 0.5 & 0.5 & - & 2.70 & 0.1 & 1.35 & $<0.0$ \\
\hline Crustacea & 2.7 & 0.3 & 4.7 & 11.2 & 13.50 & 0.3 & 31.05 & 0.7 \\
\hline Coleoptera & 2.7 & 0.3 & 0.1 & - & 1.08 & $<0.0$ & 0.81 & $<0.0$ \\
\hline Diptera & 24.4 & 10.3 & 20.4 & 11.2 & 749.08 & 15.8 & 524.60 & 11.2 \\
\hline Ephemeroptera & 32.4 & 76.7 & 25.1 & 32.6 & 3298.32 & 69.5 & 3541.32 & 75.7 \\
\hline Hemiptera & 2.7 & 0.3 & 3.8 & 2.8 & 11.07 & 0.2 & 8.37 & 0.2 \\
\hline Lepidoptera & 2.7 & 1.1 & 4.4 & 14.0 & 14.85 & 0.3 & 40.77 & 0.9 \\
\hline Odonata & 8.1 & 1.6 & 18.8 & 8.6 & 165.24 & 3.5 & 82.62 & 1.8 \\
\hline Trichoptera & 18.9 & 8.7 & 16.5 & 14.0 & 476.28 & 10.0 & 429.03 & 9.2 \\
\hline Fish & 2.7 & 0.3 & 5.7 & 5.7 & 16.20 & 0.3 & 16.20 & 0.4 \\
\hline
\end{tabular}

diet based on fish and shrimp was reported for Paratrygon aireba (Lasso et al. 1996).

The use of a volumetric method in the fish diet analyses through the measurement of the displacement in a graduate test tube is difficult when the items possess small size or are present in small amounts (Hyslop 1980). In these cases, the biovolume, defined as the area occupied by each food type (Esteves \& Galetti Jr. 1995), can be used as an indirect measure of volume. In the present study, the advantage of the biovolume method was reinforced through the comparison between the values of the relative index of importance, calculated with the biovolume and the relative volume values.

Analyzing the diet of the species in function of the microhabitat occupied (Figures 3 and 4), a diet similarity among the two species was registered only in the rocky right margin microhabitat, suggesting resource partitioning. In spite of the small number of analyzed individuals, the data apparently indicate a more specialized diet for P. motoro, consuming more Ephemeroptera (Baetidae) in the three microhabitats, and a more generalized diet for P. falkneri, with a strong 
Table 3. Food items consumed by Potamotrygon falkneri and their frequency of occurrence (FO\%), numerical frequency (NF\%), biovolume (B\%), and relative volume (RV\%). The Relative Index of Importance (RII) was calculated using the biovolume and the relative volume values. The numbers in bold represent the predominant items in the diet $(>20 \%)$

Tabela 3. Itens alimentares consumidos por Potamotrygon falkneri e sua freqüência de ocorrência (FO\%), freqüência numérica (NF\%), biovolume (B\%) e volume relativo (RV\%). O Índice de Importância Relativa (RII) foi calculado usando os valores do biovolume e do volume relativo. Os números em negrito representam os itens predominantes na dieta $(>20 \%)$.

\begin{tabular}{|c|c|c|c|c|c|c|c|c|}
\hline \multirow[t]{2}{*}{ Consumed food } & \multirow[t]{2}{*}{ FO } & \multirow[t]{2}{*}{ NF } & \multirow[t]{2}{*}{ B } & \multirow[t]{2}{*}{$\mathbf{R V}$} & \multicolumn{2}{|c|}{ RII (biovolume) } & \multicolumn{2}{|c|}{ RII (relative volume) } \\
\hline & & & & & RII & RII \% & RII & RII \% \\
\hline Mollusca & 22.7 & 11.8 & 39.6 & 0.7 & 1166.78 & 36.1 & 283.75 & 14.0 \\
\hline Crustacea & 4.6 & 2.0 & - & 5.4 & - & - & 34.04 & 1.7 \\
\hline Diptera & 4.6 & 11.8 & 1.9 & 0.1 & 63.02 & 2.0 & 54.74 & 2.7 \\
\hline Ephemeroptera & 13.6 & 15.7 & 2.4 & 0.2 & 246.16 & 7.6 & 216.24 & 10.6 \\
\hline Hemiptera & 13.6 & 25.5 & 36.8 & 1.3 & 847.28 & 26.2 & 364.48 & 18.0 \\
\hline Odonata & 9.1 & 9.8 & 13.1 & 0.8 & 208.39 & 6.0 & 96.46 & 4.8 \\
\hline Trichoptera & 27.3 & 19.6 & 6.2 & 0.3 & 704.34 & 21.8 & 543.27 & 26.8 \\
\hline Fish & 4.6 & 3.9 & - & 91.2 & - & - & 437.46 & 21.5 \\
\hline
\end{tabular}
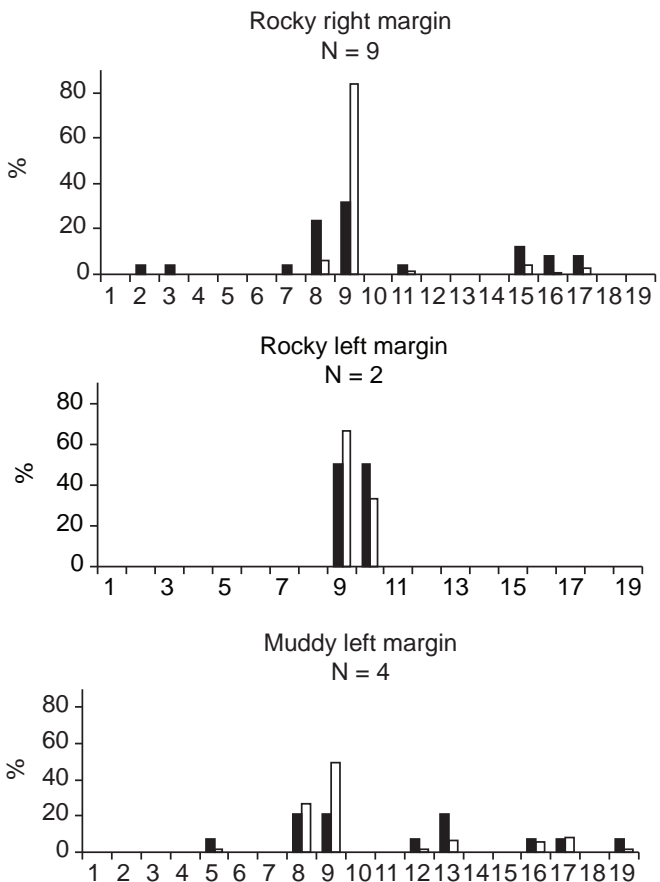

Figure 3. Frequency of occurrence (black bars) and numerical frequency (white bars) of the food items consumed by Potamotrygon motoro in the three studied microhabitats. $\mathrm{N}=$ number of individuals with stomach content. 1) Bivalvia (fragments); 2) Gastropoda (Ampullariidae); 3 ) Gastropoda (Hydrobiidae); 4) Gastropoda (fragments); 5) Crustacea (Palaemonidae); 6) Crustacea (fragments); 7) Coleoptera (Elmidae); 8) Diptera (Chironomidae); 9) Ephemeroptera (Baetidae); 10) Hemiptera (Naucoridae); 11) Lepidoptera (Pyralidae); 12) Odonata (Cordullidae); 13) Odonata (Gomphidae); 14) Odonata (Libellulidae); 15) Trichoptera (Hydropsychidae); 16) Trichoptera (Leptoceridae); 17) Trichoptera (Odontoceridae); 18) Fish (Loricariidae); and 19) Fish (fragments)

Figura 3. Freqüência de ocorrência (barras pretas) e freqüência numérica (barras brancas) dos itens alimentares consumidos por Potamotrygon motoro nos três microhabitats estudados. $\mathrm{N}=$ número de indivíduos com conteúdo estomacal. 1) Bivalvia (fragmentos); 2) Gastropoda (Ampullariidae); 3) Gastropoda (Hydrobiidae); 4) Gastropoda (fragmentos); 5) Crustacea (Palaemonidae); 6) Crustacea (fragmentos); 7) Coleoptera (Elmidae); 8) Diptera (Chironomidae); 9) Ephemeroptera (Baetidae); 10) Hemiptera (Naucoridae); 11) Lepidoptera (Pyralidae); 12) Odonata (Cordullidae); 13) Odonata (Gomphidae); 14) Odonata (Libellulidae); 15) Trichoptera (Hydropsychidae); 16) Trichoptera (Leptoceridae); 17) Trichoptera (Odontoceridae); 18) Peixe (Loricariidae); e 19) Peixe (fragmentos).

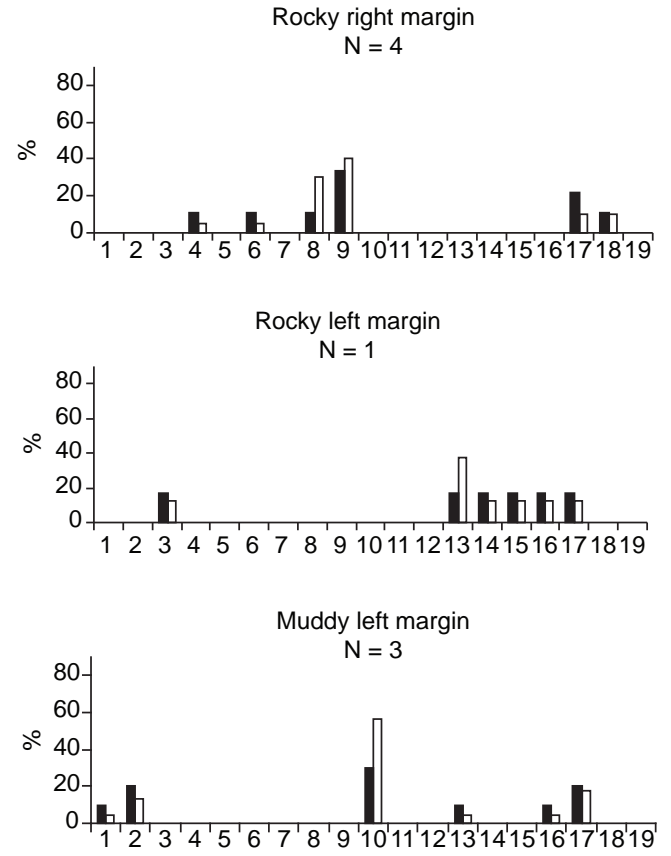

Figure 4. Frequency of occurrence (black bars) and numerical frequency (white bars) of the food items consumed by Potamotrygon falkneri in the three studied microhabitats. $\mathrm{N}=$ number of individuals with stomach content. 1) Bivalvia (fragments); 2) Gastropoda (Ampullariidae); 3) Gastropoda (Hydrobiidae); 4) Gastropoda (fragments); 5) Crustacea (Palaemonidae); 6) Crustacea (fragments); 7) Coleoptera (Elmidae); 8) Diptera (Chironomidae); 9) Ephemeroptera (Baetidae); 10) Hemiptera (Naucoridae); 11) Lepidoptera (Pyralidae); 12) Odonata (Cordullidae); 13) Odonata (Gomphidae); 14) Odonata (Libellulidae); 15) Trichoptera (Hydropsychidae); 16) Trichoptera (Leptoceridae); 17) Trichoptera (Odontoceridae); 18) Fish (Loricariidae); and 19) Fish (fragments).

Figura 4. Frequiência de ocorrência (barras pretas) e freqüência numérica (barras brancas) dos itens alimentares consumidos por Potamotrygon falkneri nos três microhabitats estudados. $\mathrm{N}=$ número de indivíduos com conteúdo estomacal. 1) Bivalvia (fragmentos); 2) Gastropoda (Ampullariidae); 3) Gastropoda (Hydrobiidae); 4) Gastropoda (fragmentos); 5) Crustacea (Palaemonidae); 6) Crustacea (fragmentos); 7) Coleoptera (Elmidae); 8) Diptera (Chironomidae); 9) Ephemeroptera (Baetidae); 10) Hemiptera (Naucoridae); 11) Lepidoptera (Pyralidae); 12) Odonata (Cordullidae); 13) Odonata (Gomphidae); 14) Odonata (Libellulidae); 15) Trichoptera (Hydropsychidae); 16) Trichoptera (Leptoceridae); 17) Trichoptera (Odontoceridae); 18) Peixe (Loricariidae); e 19) Peixe (fragmentos). 
spatial variation. Resource partitioning, defined as any considerable difference in the use of resources among species, like differences in diet or in temporal and spatial use of the habitat (Ross 1986), constitutes an important mechanism allowing the species coexistence. When the alimentary resources are available in abundance, they can be shared among species; on the other hand, when they are scarce, there is segregation among species through ontogenetic changes in the diet and/or differences in spatial/temporal distribution (Arcifa et al. 1991). The trophic partitioning was indicated by many authors (Zaret \& Rand 1971, Sabino \& Castro 1990, Uieda et al. 1997, Casatti 2002) as the most important mechanism allowing the coexistence of species and can be occurring with these two syntopic ray species.

\section{Acknowledgments}

We thank Domingos Garrone Neto for field assistance, photos and manuscript revision together with Rosinês Luciana da Motta; Vidal Haddad Jr. and Maria José Vilela for providing basic support for the field work; and Companhia Energética de São Paulo (CESP) for authorizing the work in the area of the Hydroelectric Power Station.

\section{References}

ACHENBACH, G.M. \& ACHENBACH, S.V.M. 1976. Notas acerca de algunas especies de "raya fluvial" (Batoidei, Potamotrygonidae) que frecuentan el sistema hidrografico del rio Paraná médio en el Departamento La Capital (Santa Fé - Argentina). Com. Mus. Prov. Cs. Nat. "Florentino Ameghino" 8:1-34.

ARAÚJO, M.L.G. 1998. Biologia Reprodutiva e Pesca de Potamotrygon sp. (Chondrichthyes - Potamotrygonidae), no Médio Rio Negro, Amazonas. Unpublished Master Thesis, Instituto Nacional de Pesquisas da Amazônia \& Universidade do Amazonas, Manaus.

ARCIFA, M.S., NORTHCOTE, T.G. \& FROEHLICH, O. 1991. Interactive ecology of two cohabiting characin fishes (Astyanax fasciatus and Astyanax bimaculatus) in an eutrophic Brazilian reservoir. J. Trop. Ecol. 7:257-268.

BRITSKI, H.A., SILIMON, K.Z.S. \& LOPES, B.S. 1999. Peixes do Pantanal: manual de identificação. Embrapa, Brasília.

CARVALHO, M.R., LOVEJOY, N.R. \& ROSA, R.S. 2003. Family Potamotrygonidae (River stringrays). In Check listo $f$ the freshwater fishes of South and Central America (R.E. Reis, S.O. Kullander \& C.J. Ferraris Jr., eds.). EDIPUCRS, Porto Alegre, p.22-28.

CASATTI, L. 2002. Alimentação dos peixes em um riacho do Parque Estadual Morro do Diabo, Bacia do Alto Paraná, sudeste do Brasil. Biota Neotrop. 2(2): http://www.biotaneotropica.org.br/v2n2/pt/abstract?artic le+BN02502022002

CASTEX, M.N. 1963a. El géreno Potamotrygon en el Paraná Médio. Com. Mus. Prov. Cs. Nat. "Florentino Ameghino" 3:150.

CASTEX, M.N. 1963b. La Raya Fluvial - Notas Histórico-Geográficas. Librería y Editorial Castellví, Santa Fé.

CHARVET-ALMEIDA, P. 2001. Ocorrência, biologia e uso das raias de água doce na baía de Marajó (Pará, Brasil), com ênfase na biologia de Plesiotrygon iwamae (Chondrichthyes: Potamotrygonidae). Unpublished Master Thesis, Museu Paraense Emílio Goeldi \& Universidade Federal do Pará, Belém.

CHARVET-ALMEIDA, P., ARAÚJO, M.L.G., ROSA, R.S. \& RINCÓN, G. 2002. Neotropical freshwater stingrays: diversity and conservation status. Shark News 14:47-51.

COMPAGNO, L.J.V. \& COOK, S.F. 1995. The exploitation and conservation of freshwater elasmobranchs: status of taxa and prospects for the future. J. Aquaricult. Aquat. Sci. 7:62-90.

ESTEVES, K.E. \& GALETTI Jr., P.M. 1995. Food partitioning among some characids of a small Brazilian foodplain lake from the Paraná River basin. Env. Biol. Fish 42:375-389.

HADDAD Jr., V., GARRONE NETO, D., PAULA NETO, J.B., MARQUES, F.P.L. \& BARBARO, K.C. 2004. Freshwater stingrays: study of epidemio- logic, clinic and therapeutic aspects based on 84 envenoming in humans and some enzymatic actives of the venom. Toxicon 48:287-294.

HYSLOP, E.J. 1980. Stomach contents analysis-a review of methods and their application. J. Fish Biol. 17:411-429.

LASSO, C.A., RIAL B., A. \& LASSO-ALCALA, O. 1996. Notes on the biology of the freshwater stingrays Paratrygon aiereba (Müller \& Henle, 1841) and Potamotrygon orbignyi (Castelnau, 1855) (Chondrichthyes: Potamotrygonidae) in Venezuelan llanos. Aqua 2(3):39-52.

LOPRETO, E.C. \& TELL, G. 1995. Ecossistemas de aguas continentales. Metodologias para su estudio. Ediciones Sur, Argentina.

LOWE-MCCONNELL, R.H. 1999. Estudos ecológicos de comunidades de peixes tropicais. EDUSP, São Paulo.

MERRIT, R.W. \& CUMMINS, K.W. 1996. An introduction to the aquatic insects of North America. 3 ed. Kendall / Hunt, Iowa.

PENNAK, R.W. 1978. Fresh-water invertebrates of the United States. 2 ed. John Wiley \& Sons, New York.

PINKAS, L., OLIPHANT, M.S. \& IVERSON, I.L.K. 1971. Food habit of albacore, bluefin tuna and bonito in Californian Waters. Calif. Fish Game 152:1-105.

RINGUELET, R.A. 1976. Fauna de agua dulce de La Republica Argentina. FECIC, Argentina.

ROSA, R.S. 1985. A systematic revision of the South American freshwater stingrays (Chondrichthyes: Potamotrygonidae). Unpublished Ph.D. Dissertation, The College of William and Mary, Williamsburg.

ROSS, S.T. 1986. Resource partitioning in fish assemblages: a review of field studies. Copeia 1986(2):352-388.

SABINO, J. \& CASTRO, R.M.C. 1990. Alimentação, período de atividade e distribuição espacial dos peixes de um riacho da floresta Atlântica (Sudeste do Brasil). Rev. Bras. Biol. 50:23-36.

THORSON, T.B., LANGHAMMER, J.K. \& OETINGER, M.I. 1983. Reproduction and development of the South American freshwater stingrays, Potamotrygon circularis and P. motoro. Env. Biol. Fish 9(1):3-24.

THORSON, T.B., WOOTON, R.M. \& GEORGI, T.D. 1978. Rectal gland of freshwater stingrays, Potamotrygon spp. (Chondrichthyes: Potamotrygonidae). Biol. Bull. 154:508-516.

UIEDA, V.S., BUZZATO, P.\& KIKUCHI, R.M. 1997. Partilha de recursos alimentares em peixes em um riacho de serra do Sudeste do Brasil. An. Acad. Bras. Ci. 69:243-252.

WEATHERLEY, A.H. 1963. Notions of niche and competition among animals with especial reference to freshwater fish. Nature 197:14-17.

ZARET, T.M. \& RAND, A.S. 1971. Competition in tropical stream fishes: support for the competitive exclusion principle. Ecology 52(2):336-342.

ZAVALA-CAMIM, L.A. 1996. Introdução aos estudos sobre alimentação natural em peixes. EDUEM, Maringá.

Title: Preliminary data on the feeding habits of the freshwater stingrays Potamotrygon falkneri and Potamotrygon motoro (Potamotrygonidae) from the Upper Paraná River basin, Brazil.

Authors: Silva, TB e Uieda, VS

Biota Neotropica, Vol.7 (number 1): 2007

http://www.biotaneotropica.org.br/v7n1/pt/abstract?article+ bn02007012007

Data Received 21/04/06 - Revised 12/09/06 -

Accepted 24/01/07

ISSN 1676-0603 